\title{
A study of association between common variation in the growth hormone-chorionic somatomammotropin hormone gene cluster and adult fasting insulin in a UK Caucasian population Rachel M Freathy, Simon MS Mitchell, Beatrice Knight, Beverley Shields, Michael N Weedon, Andrew T Hattersley and Timothy M Frayling*
}

Address: Institute of Biomedical and Clinical Science, Peninsula Medical School, Exeter, UK

Email: Rachel M Freathy - rachel.freathy@pms.ac.uk; Simon MS Mitchell - S.M.S.Mitchell@student.liverpool.ac.uk; Beatrice Knight - B.A.Knight@ex.ac.uk; Beverley Shields - B.Shields@ex.ac.uk; Michael N Weedon -m.n.weedon@ex.ac.uk; Andrew T Hattersley - andrew.hattersley@pms.ac.uk; Timothy M Frayling* - tim.frayling@pms.ac.uk

* Corresponding author

Published: 24 November 2006

Journal of Negative Results in BioMedicine 2006, 5:18 doi:10.1 186/1477-575I-5-18

This article is available from: http://www.jnrbm.com/content/5/I/l8

(C) 2006 Freathy et al; licensee BioMed Central Ltd.

This is an Open Access article distributed under the terms of the Creative Commons Attribution License (http://creativecommons.org/licenses/by/2.0), which permits unrestricted use, distribution, and reproduction in any medium, provided the original work is properly cited.

\begin{abstract}
Background: Reduced growth during infancy is associated with adult insulin resistance. In a UK Caucasian cohort, the CSHI.OI microsatellite polymorphism in the growth hormone-chorionic somatomammotropin hormone gene cluster was recently associated with increases in adult fasting insulin of approximately $23 \mathrm{pmol} / \mathrm{l}$ for TT homozygote males compared to DIDI or D2D2 homozygotes $(P=0.00 \mathrm{I}$ and $0.009 ; n=206$ and 92 , respectively), but not for females. TT males additionally had a 547 -g lower weight at I year $(n=270 ; P=0.008)$ than D2D2 males. We sought to replicate these data in healthy UK Caucasian subjects. We genotyped I396 subjects (fathers, mothers and children) from a consecutive birth study for the CSHI.OI marker and analysed genotypes for association with I-year weight in boys and fasting insulin in fathers.
\end{abstract}

Results: We found no evidence for association of $\mathrm{CSHI}$.0I genotype with adult male fasting insulin concentrations (TT/DIDI $P=0.38$; TT/D2D2 $P=0.18$ ) or weight at I year in boys (TT/DIDI $P=$ 0.76 ; TT/D2D2 $P=0.85$ ). For fasting insulin, our data can exclude the previously observed effect sizes as the $95 \%$ confidence intervals for the differences observed in our study exclude increases in fasting insulin of 9.0 and $12.6 \mathrm{pmol} / \mathrm{l}$ for TT relative to DIDI and D2D2 homozygotes, respectively. Whilst we have fewer data on boys' I-year weight than the original study, our data can exclude a reduction in I-year weight greater than $557 \mathrm{~g}$ for TT relative to D2D2 homozygotes.

Conclusion: We have not found association of the CSHI.OI genotype with fasting insulin or weight at I year. We conclude that the original study is likely to have over-estimated the effect size for fasting insulin, or that the difference in results reflects the younger age of subjects in this study relative to those in the previous study.

\section{Background}

Reduced birth weight and reduced growth in infancy are associated with adult disorders characterised by insulin resistance in the general population [1-5]. These include type 2 diabetes, coronary heart disease and hypertension. Their association with birth weight may be explained by 
programming of metabolism due to undernutrition in utero [1], or by genetic factors: common genetic variants which increase insulin resistance may predispose both to low insulin-mediated growth in utero and insulin resistance in adulthood [6]. It has been proposed that infant length or weight measured up to the age of two increasingly reflects the influence of the infant's own genes on the growth trajectory since the influence of the maternal intra-uterine environment is no longer present $[7,8]$. Since reduced weight in infancy is also associated with adult insulin resistance, candidate genes with effects on both of these traits, as well as birth weight may explain the observed associations.

Few genes are known to influence both diabetes-related traits and birth weight. Positive associations with both phenotypes have been shown for the insulin gene (INS) variable number of tandem repeats (VNTR) locus [8-10], a microsatellite polymorphism in the insulin-like growth factor 1 gene (IGF1) [11,12] and the glucokinase gene GCK(-30) polymorphism [13]. There is evidence that a single nucleotide polymorphism in complete linkage disequilibrium with INS-VNTR classes I and III (rs689) is functional [14]. Despite this, studies attempting to replicate the INS-VNTR and IGF1 associations have produced inconsistent results [15-20]. Replication of any genetic association study is vital for determining whether the observed association is real, since it increases the cumulative sample size and helps to guard against the low a priori odds of a variant altering a phenotype, which may hinder any single study $[21,22]$.

Recently, Day et al. [23] reported that genetic variation in the $\mathrm{GH} / \mathrm{CSH}$ gene cluster, which includes growth hormone (GH1; chromosome 17q23), is associated with altered 1-year weight and adult insulin resistance in UK Caucasian males aged 59-72 years. Variation in a highly polymorphic microsatellite marker, CSH1.01, was dichotomised into allele lineages based on possession of a dinucleotide repeat allele (D1; D2 (subset)) or a tetranucleotide repeat allele $(\mathrm{T})$. In male subjects from north and east Hertfordshire, TT homozygotes had a 64.6 $\%$ (22.8 pmol/l) or $66.5 \%$ (23.2 pmol/l) higher fasting insulin compared to D1D1 homozygotes $(P=0.001 ; n=$ $206)$ and D2D2 homozygotes $(P=0.009 ; n=92)$, respectively. The TT genotype was also associated with a $5.3 \%$ $(547 \mathrm{~g})$ reduction in weight at 1 year compared to the D2D2 genotype $(P=0.008 ; n=270)$ but this difference was not observed when compared to the D1D1 genotype $(P=0.24 ; n=593)$. There was no association of genotype with birth weight, and no association with any measured phenotype in females.

Strong linkage disequilibrium occurs across the 66.5-kb $\mathrm{GH} / \mathrm{CSH}$ gene cluster such that variation in two or more of the genes, inherited together, may reduce growth in early life while predisposing to disease later in life [23]. The gene cluster is an excellent candidate region for predisposing to restricted early growth and later insulin resistance. Placental growth hormone (GH2) and chorionic somatomammotropin (human placental lactogen) hormones 1 and 2 (CSH1 and CSH2), are expressed in the placenta and are involved in regulating fetal glucose supply and growth $[24,25]$. GH1, through transcriptional regulation of the gene for insulin-like growth factor-I (IGF1) and related genes, has a critical role in the regulation of postnatal growth [26]. Exogenous growth hormone administration alters glucose metabolism both in vitro and in vivo [27], whilst growth hormone deficiency and acromegaly are characterised respectively by sensitivity and resistance to insulin [28]. In addition, lower circulating IGF-I concentrations are associated with higher risk of impaired glucose tolerance or type 2 diabetes [29].

We sought replication of the associations reported by Day et al. [23]. We used healthy subjects (483 fathers, 479 mothers and 434 children) from a population-based consecutive birth study to assess the role of CSH1.01 variation in measures of fetal and postnatal growth and adult insulin resistance, as measured by fasting insulin concentrations and Homeostasis Model Assessment of Insulin Sensitivity (HOMA \%S).

\section{Results}

\section{CSHI.0I genotype and fathers' fasting insulin}

There was no association between father's D1/T or D2/T genotype and fasting insulin (Table 1 ). The $P$ values for fathers' fasting insulin were little changed by adjustment for age and BMI $(P=0.53$ and 0.29 for the D1/T and D2/ T genotypes, respectively).

\section{CSHI.0I genotype and children's weight at I year}

There was no association between children's D1/T or D2/ T genotype and weight at 1 year (Table 1 shows results for all children, and also separately for boys and girls). The $P$ values for children's $1 \mathrm{yr}$ weight were little changed by adjustment for sex $(P=0.49$ and 0.66 for the D1/T and D2/T genotypes, respectively).

\section{CSHI.0I genotype and other relevant phenotypes}

There was also no association of D1/T or D2/T genotype with fathers' HOMA \%S, children's birth weight (all children born at 36 weeks gestation or more, or stratified by sex) or placental weight (gestation 36 weeks or more), father or mother's height, father or mother's birth weight (obtained from subjects' mothers), father's BMI, mother's pre-pregnancy BMI, mother's age, father's age, father's fasting triglyceride concentrations adult or children's sex (all $P>0.05$; results not shown). Oral glucose tolerance 
Table I: Phenotypes previously reported as associated with the CSHI.0I microsatellite by Day et al. [23]: Fathers' fasting insulin and boys' I year weight (with $95 \%$ confidence limits) tabulated for CSHI.0I allele group DI/T and D2/T genotypes

\begin{tabular}{|c|c|c|c|c|c|c|c|c|c|c|}
\hline & $\mathrm{T} / \mathrm{T}$ & $\mathrm{DI} / \mathrm{T}$ & DI/DI & $\mathrm{N}$ & $P$ & $\mathrm{~T} / \mathrm{T}$ & $\mathrm{D} 2 / \mathrm{T}$ & D2/D2 & $\mathrm{N}$ & $P$ \\
\hline $\begin{array}{l}\text { Fathers: fasting } \\
\text { insulin (pmol/l) }\end{array}$ & $\begin{array}{c}54.1 \\
(46.1-63.5)\end{array}$ & $\begin{array}{c}51.6 \\
(47.9-55.7)\end{array}$ & $\begin{array}{c}55.8 \\
(51.4-60.7)\end{array}$ & 472 & 0.375 & $\begin{array}{c}54.1 \\
(45.9-63.7)\end{array}$ & $\begin{array}{c}48.1 \\
(42.9-54.0)\end{array}$ & $\begin{array}{c}57.9 \\
(48.3-69.3)\end{array}$ & 196 & 0.183 \\
\hline $\begin{array}{l}\text { Children: I yr weight } \\
\text { (g) }\end{array}$ & $\begin{array}{c}9786 \\
(9457-10115)\end{array}$ & $\begin{array}{c}9992 \\
(9818-10167)\end{array}$ & $\begin{array}{c}9946 \\
(9763-10129)\end{array}$ & 366 & 0.554 & $\begin{array}{c}9786 \\
(946 I-10 I \mid 2)\end{array}$ & $\begin{array}{c}99 / 4 \\
(9670-10157)\end{array}$ & $\begin{array}{c}10057 \\
(9669-10445)\end{array}$ & 164 & 0.572 \\
\hline Girls: I yr weight (g) & $\begin{array}{c}9087 \\
(8638-9536)\end{array}$ & $\begin{array}{c}9610 \\
(9375-9846)\end{array}$ & $\begin{array}{c}9633 \\
(9388-9877)\end{array}$ & 176 & 0.092 & $\begin{array}{c}9087 \\
(8648-9526)\end{array}$ & $\begin{array}{c}9541 \\
(9216-9867)\end{array}$ & $\begin{array}{c}9688 \\
(9117-10259)\end{array}$ & 75 & 0.164 \\
\hline Boys: I yr weight (g) & $\begin{array}{c}10401 \\
(9969-10834)\end{array}$ & $\begin{array}{c}10344 \\
(10112-10575)\end{array}$ & $\begin{array}{c}10242 \\
(9998-10487)\end{array}$ & 190 & 0.758 & $\begin{array}{c}10401 \\
(9984-10819)\end{array}$ & $\begin{array}{c}10252 \\
(9937-10567)\end{array}$ & $\begin{array}{c}10297 \\
(9829-10764)\end{array}$ & 89 & 0.851 \\
\hline
\end{tabular}

Fasting insulin and weight measures are unadjusted mean ( $95 \%$ confidence limits). Fasting insulin values were log-transformed before analysis. $P$ values are for one-way ANOVA.

test and blood pressure data were not available for these subjects.

\section{Discussion}

Common variants in the GH-CSH cluster are excellent candidates for contributing to common variation in fetal/ infant growth and adult insulin resistance. The placentally-expressed CSH1, CSH2 and GH2 genes have key roles in the regulation of fetal glucose supply and growth $[24,25]$, while GH1 has a critical role in postnatal growth and glucose metabolism [26-29]. A previous study reported that a microsatellite polymorphism in this cluster, CSH1.01, was associated with reduced weight at 1 year and increased fasting insulin concentrations in adult UK Caucasian males [23]. We have examined this polymorphism in an independent UK Caucasian study and found no evidence of association with either phenotype.

Our study included over twice as many adult male subjects for the fasting insulin analysis as the previous study [23]. This gave us more statistical power to detect an effect of genotype. Whereas Day et al. [23] showed that fasting insulin concentrations of TT carriers were $22.8 \mathrm{pmol} / \mathrm{l}$ higher than those of D1D1 carriers and $23.2 \mathrm{pmol} / \mathrm{l}$ higher than those of D2D2 carriers $(P=0.009$ and 0.008 , respectively), we found no evidence of a difference and the $95 \%$ confidence limits for the differences observed in our study exclude increases in fasting insulin above 9.0 and $12.6 \mathrm{pmol} / \mathrm{l}$ for TT relative to D1D1 and D2D2 homozygotes respectively. Using unlogged fasting insulin data, we obtained a more conservative estimate, but still are able to exclude increases in fasting insulin above 15.4 and $17.8 \mathrm{pmol} / \mathrm{l}$ for TT relative to D1D1 and D2D2 homozygotes, respectively. Our data suggest that the initial finding may have been a false-positive result or an over-estimation of the effect size. Both of these are a common problem for genetic association studies [30]. Further large-scale studies involving thousands, or tens of thousands of subjects will be required to investigate the possibility of smaller effect sizes. Another factor which may account for the differing result is that adult males in our study were younger (median age 33 years) than those in the previous study (age range 59-72 years). It is possible that the relationship between genotype and fasting insulin is modified by age. Some studies have reported geneage interactions after results across all ages showed a weak association, for example the recent study of the relationship between the Leu262Val variant in the PSARL gene and plasma insulin in human subjects [31]. As with simple gene-phenotype associations, these interactions require replication. To investigate this possibility further, it will be necessary to carry out large-scale studies of CSH1.01 and fasting insulin in individuals spanning a wide range of ages.

We found no evidence of an association of CSH1.01 genotype with weight at 1 year. This contrasts with the results of Day et al. [23], who reported a $547 \mathrm{~g}$ reduction in weight at 1 year $(P=0.008 ; n=270)$ for TT compared to D2D2 males. Our data show a non-significant trend of 1year weight values across the $\mathrm{D} 1 / \mathrm{T}$ genotypes, in the opposite direction to that observed in the original study. Whilst we had reduced power to detect differences in weight at 1 year, the $95 \%$ confidence limits for the difference observed in our study $(-557 \mathrm{~g},+767 \mathrm{~g})$ exclude reductions in 1-year weight greater than $557 \mathrm{~g}$ for TT relative to D2D2 homozygote males. Whilst our data on female weight at 1 year are suggestive of an association of the same magnitude and direction as was seen for D2/T males in the original study, we acknowledge our reduced statistical power and conclude that further well-powered studies will be needed to confirm the role of this variant in fetal and infant growth.

This study focused on one variant within the GH-CSH gene cluster. Whilst we have not captured fully the common variation in this candidate region, we have examined a polymorphism previously associated with fasting insulin in males with a large effect size, but found no evidence for this in our larger sample. 


\section{Conclusion}

Replication of genetic association data in independent studies is vital for determining whether an initially observed association is a consistent finding. We have found no evidence that the CSH1.01 microsatellite polymorphism is associated with adult male fasting insulin in this larger replication study. We conclude that the result of the initial association study [23] is either a false positive, an over-estimation of the effect size for this phenotype, or a reflection of substantial heterogeneity between the two samples as a result of age differences. Further large-scale studies which capture more of the variation in the $\mathrm{GH}$ $\mathrm{CSH}$ region will clarify its potential role in influencing fetal and infant growth and adult insulin resistance.

\section{Methods \\ Subjects}

Subjects were UK Caucasian fathers $(n=483)$, mothers $(n$ $=479)$ and children $(n=434)$ from the Exeter Family Study of Childhood Health [32]. The clinical characteristics of subjects are shown in Table 2. All recruited subjects gave their informed consent. The study was approved by local research ethics committee and the protocol conforms to the ethical guidelines of the World Medical Association Declaration of Helsinki.

\section{Genotyping and quality control}

Genomic DNA was isolated from leukocytes using standard techniques. The CSH1.01 microsatellite polymorphism was amplified by PCR using the following primers: forward 5'-GTT TAC TGC ACT CCA GCC TCG GAG-3'; reverse 5'-ACA AAA GTC CTT TCT CCA GAG CA-3'. A 5'GTTT "PIGtail" was added to the forward primer to reduce the occurrence of non-templated A-addition. The forward primer was also labelled with the FAM fluorochrome. The
PCR was performed in a final volume of $10 \mu \mathrm{l}$ containing $16 \mathrm{ng}$ genomic DNA, $2.5 \mathrm{pmol}$ each primer, $2.25 \mathrm{mmol} / \mathrm{l}$ $\mathrm{MgCl}_{2}, 0.25 \mathrm{mmol} / \mathrm{l}$ each of deoxy-ATP, -CTP, -GTP and TTP and 0.25 units Amplitaq Gold DNA polymerase (Applied Biosystems, Warrington, UK). The reaction started with 12 min denaturation at $94^{\circ} \mathrm{C}$, followed by 12 cycles of denaturation at $94^{\circ} \mathrm{C}$ for $30 \mathrm{~s}$, annealing at $54^{\circ} \mathrm{C}$ for $30 \mathrm{~s}$ and extension at $72^{\circ} \mathrm{C}$ for $1 \mathrm{~min}$. For 23 more cycles, the denaturation temperature was lowered to $89^{\circ} \mathrm{C}$. The PCR was completed by a final extension at $72^{\circ} \mathrm{C}$ for $10 \mathrm{~min}$. Products were separated on a standard polyacrylamide sequencing gel using the $\mathrm{ABI} 377$ autosequencer and analysed using GENESCAN and GENOTYPER software (Applied Biosystems). Control samples of known genotype were used in each PCR and every polyacrylamide gel to monitor genotyping consistency. These initially included samples genotyped in the previous study [23] for comparison. Negative controls $\left(\mathrm{H}_{2} \mathrm{O}\right)$ were also included to monitor potential contamination. The overall genotyping assay success rate was $83 \%$. Genotypes were in Hardy-Weinberg Equilibrium $(P=0.98$ and 0.66 for D1/T and D2/T genotypes respectively). Genotyping accuracy, as determined from the genotype concordance between duplicate samples (11\% of total) was $99 \%$. Families showing Mendelian inconsistencies were excluded from analyses. Allele frequency distributions were similar in our study to that of Day et al. with a $\mathrm{T}$ allele frequency of 0.35 , similar to the previously-reported figure of 0.34 [23].

\section{Classification of CSHI.0I alleles and statistical analyses}

Alleles were dichotomized into D1/T or D2/T allele categories in exactly the same way as for the study by Day et al. [23]: alleles 271-311 nt were classified as T; alleles less than $271 \mathrm{nt}$ were classified as D1; alleles 251, 255, 259,

Table 2: Clinical characteristics of subjects

\begin{tabular}{|c|c|c|c|}
\hline & \multicolumn{3}{|c|}{ Exeter Family Study Subjects } \\
\hline & Fathers & Mothers & Children \\
\hline$n$ & 483 & 479 & 434 \\
\hline Male (\%) & - & - & 51.6 \\
\hline Birth weight for children born $>36$ weeks gestation $(\mathrm{g})$ & - & - & $3500(3175-3780)$ \\
\hline Weight at I year $(\mathrm{g})$ & - & - & $9854(9 \mid 46-10730) \ddagger$ \\
\hline Age (years) & $33(29-36)$ & $31(27-34)$ & - \\
\hline $\mathrm{BMI}\left(\mathrm{kg} / \mathrm{m}^{2}\right)$ & $26.2(24.0-28.7)$ & $23.1(21.2-25.4)^{*}$ & - \\
\hline Height $(\mathrm{cm})$ & $178.0(173.5-182.4)$ & $164.9(160.7-169.2)$ & - \\
\hline Reported birth weight $(\mathrm{g})$ & $3402(3005-3770)$ & $3289(3005-3629)$ & - \\
\hline Fasting blood glucose (mmol/l) & $4.7(4.4-5.0)$ & $4.3(4.1-4.6)^{\dagger}$ & - \\
\hline Fasting insulin (pmol/l) & $49.0(37.0-78.1)$ & $59.2(43.4-85.0)^{\dagger}$ & - \\
\hline
\end{tabular}

Continuous data are given as median (interquartile range). Subjects successfully genotyped for the CSHI.0I microsatellite are included. *Pre-pregnancy BMI.

tMeasurements taken at 28 weeks gestation.

¥Data on weight at I year were available for 366 children. 
263 and 267 nt were excluded from the D1 group to define the D2 group. Decisions relating to placement of the D1/T boundary and exclusion of alleles to create the D2 allele group were informed by comparison of our allele frequency distribution with that reported by Day et al. [23]. The CSH1.01 allele frequency distribution is shown in Figure 1.

We used Chi-squared tests to assess whether the genotypes of parents were in Hardy-Weinberg Equilibrium. We used General Linear Models in SPSS v.11.5 for Windows to test for association between $\mathrm{D} 1 / \mathrm{T}$ or $\mathrm{D} 2 / \mathrm{T}$ genotype and selected phenotypes of fathers, mothers or children: fasting insulin and HOMA \%S (fathers only: mothers were pregnant (28 weeks gestation) at the time of data collection); height (mothers and fathers); placental weight; 1 year weight and birth weight (children). Analyses were performed both on uncorrected data and on data corrected for age and BMI (fasting insulin), sex and gestation (birth weight; placental weight) and sex (1 year weight). The $95 \%$ confidence limits for the differences in fasting insulin observed in our study (TT relative to D1D1 and D2D2 homozygotes) were calculated using the antilog transformation and converting from the ratios obtained [33]

We had $>92 \%$ power to detect the differences in adult male fasting insulin observed in the previously published study, i.e. increases of $22.8 \mathrm{pmol} / \mathrm{l}$ for TT relative to D1D1 homozygotes, and $23.2 \mathrm{pmol} / \mathrm{l}$ for TT relative to D2D2 homozygotes [23]. We had $80 \%$ power to detect increases in adult male fasting insulin of $13.6 \mathrm{pmol} / \mathrm{l}$ for TT relative to D1D1 homozygotes, and of $18.9 \mathrm{pmol} / \mathrm{l}$ for TT relative to D2D2 homozygotes $(P<0.05$ for difference in same direction as original study, assuming $\mathrm{T}$ allele frequency of 0.35 ). We had $80 \%$ power to detect decreases in boys' weight at 1 year of $830 \mathrm{~g}$ for TT relative to D2D2 homozygotes ( $P$ value $<0.05$; same direction as original study). We had reduced power $(50 \%)$ to detect the decrease of 547 g originally observed [23].

\section{Abbreviations}

BMI, body mass index; CSH1, chorionic somatomammotropin hormone 1 ; $\mathrm{CSH} 2$, chorionic somatomammotropin hormone 2; GH1, growth hormone; GH2, placental growth hormone; GH-CSH, growth hormone-chorionic somatomammotropin hormone gene cluster; HOMA \%S,

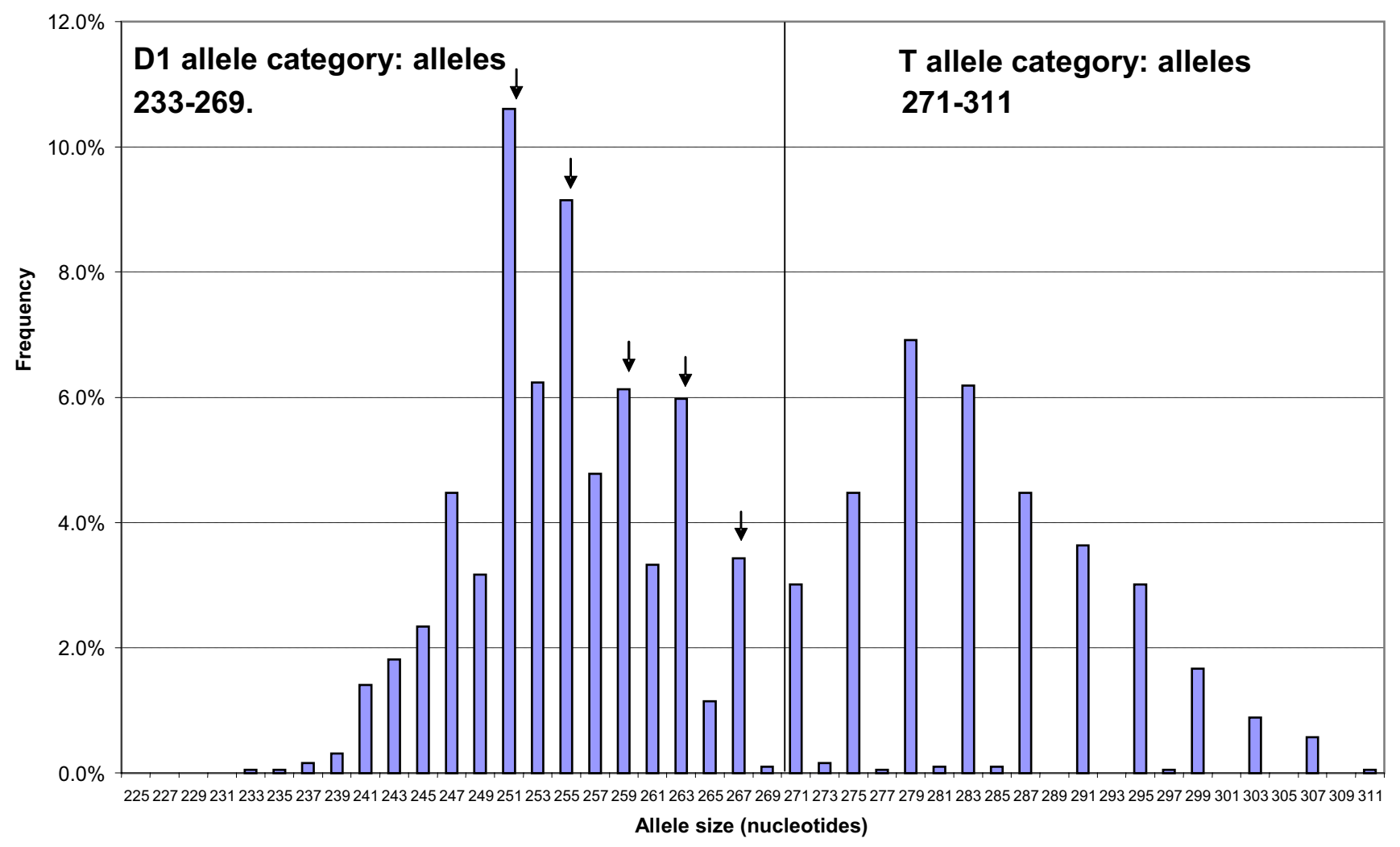

Figure I

CSHI.OI allele frequency distribution (Exeter Family Study parents; $\mathbf{N}=1924$ alleles). Alleles marked by arrows were excluded from the DI allele category to form the D2 category. 
Homeostasis Model Assessment of Insulin Sensitivity; IGF1, insulin-like growth factor 1; INS-VNTR, insulin gene variable number of tandem repeats; PCR, polymerase chain reaction.

\section{Competing interests}

The authors declare that they have no competing interests.

\section{Authors' contributions}

RMF and SMSM carried out the genotyping. RMF carried out the data analysis and drafted the manuscript. BK was responsible for sample recruitment and collection and measurements of anthropometric phenotypes. MNW and BS were responsible for database management. ATH and TMF conceived and designed the study. TMF co-ordinated the study and supervised the redrafting of the manuscript. All authors read and approved the final manuscript.

\section{Acknowledgements}

We thank lan Day and Tom Gaunt from Southampton University Hospital for providing positive control samples for genotyping and for helpful advice. R. M. Freathy holds a Diabetes U. K. research studentship. A. T. Hattersley is a Wellcome Trust Research Leave Fellow, and M. N. Weedon, a Vandervell Foundation Research Fellow.

\section{References}

I. Barker DJ, Bull AR, Osmond C, Simmonds SJ: Fetal and placental size and risk of hypertension in adult life. Bmj 1990 30 I(6746):259-262

2. Hales CN, Barker DJ, Clark PM, Cox LJ, Fall C, Osmond C, Winter PD: Fetal and infant growth and impaired glucose tolerance at age 64. Bmj 1991, 303(6809): 1019-1022.

3. Barker DJ, Godfrey KM, Osmond C, Bull A: The relation of fetal length, ponderal index and head circumference to blood pressure and the risk of hypertension in adult life. Paediatr Perinat Epidemiol 1992, 6(1):35-44.

4. Barker DJ: Fetal origins of coronary heart disease. Bmj I995, 3 I I(6998): I7|- I74.

5. Barker DJ: Fetal programming of coronary heart disease. Trends Endocrinol Metab 2002, I3(9):364-368.

6. Hattersley AT, Tooke JE: The fetal insulin hypothesis: an alternative explanation of the association of low birthweight with diabetes and vascular disease. Lancet 1999, 353(9 | 66): $1789-1792$.

7. Smith DW, Truog W, Rogers JE, Greitzer LJ, Skinner AL, McCann JJ, Harvey MA: Shifting linear growth during infancy: illustration of genetic factors in growth from fetal life through infancy. Pediatr 1976, 89(2):225-230.

8. Dunger DB, Ong KK, Huxtable SJ, Sherriff A, Woods KA, Ahmed ML, Golding J, Pembrey ME, Ring S, Bennett ST, Todd JA: Association of the INS VNTR with size at birth. ALSPAC Study Team. Avon Longitudinal Study of Pregnancy and Childhood. Nat Genet 1998, I 9(I):98-100.

9. Bennett ST, Todd JA: Human type I diabetes and the insulin gene: principles of mapping polygenes. Annu Rev Genet 1996, 30:343-370.

10. Le Stunff C, Fallin D, Schork NJ, Bougneres P: The insulin gene VNTR is associated with fasting insulin levels and development of juvenile obesity. Nat Genet 2000, 26(4):444-446.

I I. Vaessen N, Heutink P, Janssen JA, Witteman JC, Testers L, Hofman A, Lamberts SW, Oostra BA, Pols HA, van Duijn CM: A polymorphism in the gene for IGF-I: functional properties and risk for type 2 diabetes and myocardial infarction. Diabetes 200I, 50(3):637-642.

12. Vaessen N, Janssen JA, Heutink P, Hofman A, Lamberts SW, Oostra $\mathrm{BA}$, Pols HA, van Duijn CM: Association between genetic varia- tion in the gene for insulin-like growth factor-I and low birthweight. Lancet 2002, 359(93 II): 1036-1037.

13. Weedon MN, Frayling TM, Shields B, Knight B, Turner T, Metcalf BS, Voss L, Wilkin TJ, McCarthy A, Ben-Shlomo Y, Davey Smith G, Ring S, Jones R, Golding J, Byberg L, Mann V, Axelsson T, Syvanen AC, Leon D, Hattersley AT: Genetic regulation of birth weight and fasting glucose by a common polymorphism in the islet cell promoter of the glucokinase gene. Diabetes 2005, 54(2):576-58I.

14. Kralovicova J, Gaunt TR, Rodriguez S, Wood PJ, Day IN, Vorechovsky $\mathrm{I}:$ Variants in the human insulin gene that affect pre-mRNA splicing: is $-23 \mathrm{Hphl}$ a functional single nucleotide polymorphism at IDDM2? Diabetes 2006, 55(I):260-264.

15. Lindsay RS, Hanson RL, Wiedrich C, Knowler WC, Bennett PH, Baier LI: The insulin gene variable number tandem repeat class I/ III polymorphism is in linkage disequilibrium with birth weight but not Type 2 diabetes in the Pima population. Diabetes 2003, 52(I): 187-193.

16. Mitchell SM, Hattersley AT, Knight B, Turner T, Metcalf BS, Voss LD, Davies D, McCarthy A, Wilkin TJ, Smith GD, Ben-Shlomo Y, Frayling TM: Lack of support for a role of the insulin gene variable number of tandem repeats minisatellite (INS-VNTR) locus in fetal growth or type $\mathbf{2}$ diabetes-related intermediate traits in United Kingdom populations. J Clin Endocrinol Metab 2004, 89(1):310-317.

17. Ong KK, Petry CJ, Barratt BJ, Ring S, Cordell HJ, Wingate DL, Pembrey ME, Todd JA, Dunger DB: Maternal-fetal interactions and birth order influence insulin variable number of tandem repeats allele class associations with head size at birth and childhood weight gain. Diabetes 2004, 53(4): I I 28-I I33.

18. Hansen SK, Gjesing AP, Rasmussen SK, Glumer C, Urhammer SA Andersen G, Rose CS, Drivsholm T, Torekov SK, Jensen DP, Ekstrom $\mathrm{CT}$, Borch-Johnsen K, Jorgensen T, McCarthy MI, Hansen T, Pedersen $\mathrm{O}$ : Large-scale studies of the $\mathrm{Hphl}$ insulin gene variablenumber-of-tandem-repeats polymorphism in relation to Type 2 diabetes mellitus and insulin release. Diabetologia 2004, 47(6): 1079-1087.

19. Bennett AJ, Sovio U, Ruokonen A, Martikainen H, Pouta A, Taponen S, Hartikainen AL, King VJ, Elliott P, Jarvelin MR, McCarthy MI: Variation at the insulin gene VNTR (variable number tandem repeat) polymorphism and early growth: studies in a large Finnish birth cohort. Diabetes 2004, 53(8):2|26-2I3I.

20. Frayling TM, Hattersley AT, McCarthy A, Holly J, Mitchell SM, Gloyn AL, Owen K, Davies D, Smith GD, Ben-Shlomo Y: A putative functional polymorphism in the IGF-I gene: association studies with type 2 diabetes, adult height, glucose tolerance, and fetal growth in U.K. populations. Diabetes 2002, 5 I(7):23|3-23|6.

21. Page GP, George V, Go RC, Page PZ, Allison DB: "Are we there yet?": Deciding when one has demonstrated specific genetic causation in complex diseases and quantitative traits. $\mathrm{Am} J$ Hum Genet 2003, 73(4):71 I-7I9.

22. McCarthy MI, Groop PH, Hansen T: Making the right associations. Diabetologia 2005, 48(7): $|24|-1243$.

23. Day IN, Chen XH, Gaunt TR, King TH, Voropanov A, Ye S, Rodriguez S, Syddall HE, Sayer AA, Dennison EM, Tabassum F, Barker DJ, Cooper C, Phillips DI: Late life metabolic syndrome, early growth, and common polymorphism in the growth hormone and placental lactogen gene cluster. I Clin Endocrinol Metab 2004, 89(I I):5569-5576.

24. Handwerger S, Freemark M: The roles of placental growth hormone and placental lactogen in the regulation of human fetal growth and development. J Pediatr Endocrinol Metab 2000, 13(4):343-356.

25. Lacroix MC, Guibourdenche J, Frendo JL, Muller F, Evain-Brion D: Human placental growth hormone--a review. Placenta 2002 , 23 Suppl A:S87-94.

26. Rosenfeld RG: Insulin-like growth factors and the basis of growth. N Engl J Med 2003, 349(23):2 I84-2 I86

27. Butler AA, Le Roith D: Control of growth by the somatropic axis: growth hormone and the insulin-like growth factors have related and independent roles. Annu Rev Physiol 200I, 63:14I-164.

28. Jorgensen JO, Krag M, Jessen N, Norrelund H, Vestergaard ET, Moller $\mathrm{N}$, Christiansen JS: Growth hormone and glucose homeostasis. Horm Res 2004, 62 Suppl 3:5I-55. 
29. Sandhu MS, Heald AH, Gibson JM, Cruickshank JK, Dunger DB, Wareham NJ: Circulating concentrations of insulin-like growth factor-I and development of glucose intolerance: a prospective observational study. Lancet 2002, 359(93 | 9): I740- I745.

30. loannidis JP, Ntzani EE, Trikalinos TA, Contopoulos-loannidis DG: Replication validity of genetic association studies. Nat Genet 200I, 29(3):306-309.

31. Walder K, Kerr-Bayles L, Civitarese A, Jowett J, Curran J, Elliott K, Trevaskis J, Bishara N, Zimmet P, Mandarino L, Ravussin E, Blangero J, Kissebah A, Collier GR: The mitochondrial rhomboid protease PSARL is a new candidate gene for type 2 diabetes. Diabetologia 2005, 48(3):459-468.

32. Knight B, Shields BM, Hattersley AT: The Exeter Family Study of Childhood Health (EFSOCH): study protocol and methodology. Paediatr Perinat Epidemiol 2006, 20(2): I72-179.

33. Bland JM, Altman DG: The use of transformation when comparing two means. BMJ 1996, 3 I 2(7039): I I 53.

Publish with Biomed Central and every scientist can read your work free of charge

"BioMed Central will be the most significant development for disseminating the results of biomedical research in our lifetime. "

Sir Paul Nurse, Cancer Research UK

Your research papers will be:

- available free of charge to the entire biomedical community

- peer reviewed and published immediately upon acceptance

- cited in PubMed and archived on PubMed Central

- yours - you keep the copyright

Submit your manuscript here:

http://www.biomedcentral.com/info/publishing_adv.asp 